ABSTRACT

Mobility and Theatre: Theatre Makers as Nomadic Subjects

This article discusses the pros and cons of theatrical mobility, investigating situations where theatre is breaking its traditional practices of being local and urban by becoming mobile, international and rural. The main features in this context are guest performances at home and abroad, the importation of guest directors, performers, designers et cetera, and finally, site-specific and open-air productions. The structure of the analysis is based on these features, partly derived from the historical development of theatre but partly also from the aim of contrary thinking, insisting that contrary to the widespread assumption of nomadism as something indigenous or postmodern, nomadic attitudes can also be detected in quite traditional forms of theatre making and living. While touring at home and abroad provides opportunities for theatre makers to practice nomadic life style, summer theatre creates an opportunity for spectators to experience nomadism in more local spaces.

The above mentioned features are analysed in the context of Estonian theatre, drawing occasional parallels with the neighbouring country of Finland. Each section goes through three periods of Estonian theatre history; 1) the period before the Second World War when theatres belonged to societies; 2) the period between 1940 and 1991 when Estonia was a part of the Soviet Union and all theatrical activities were subject to state control; 3 ) the period of independence and globalization. Since each period had a different imprint on theatrical mobility, the phenomenon will be investigated in relation to the political, social and cultural contexts, using Bruno Latour's concept of actor-network-theory as a methodological tool.

Keywords: Estonian theatre, mobility, touring, internationalisation, summer theatre, nomadism, actor-network-theory.

BIOGRAPHY

Anneli Saro is Professor of Theatre Research at the University of Tartu (Estonia) and the Editor-in-Chief of Nordic Theatre Studies. She has been a convener of the international working group Project on European Theatre Systems (20042008 ) and is presently convener of The Theatrical Event working group. Saro was also a member of the executive committee of the International Federation for Theatre Research. She has published articles on audience research, performance analysis, Estonian theatre history and systems. 


\section{Mobility and Theatre Theatre Makers as Nomadic Subjects ${ }^{1}$}

\section{ANNELI SARO}

During the twentieth century, theatre has been considered to be more local than global, more institutional and urban than rural. In my paper, I am going to analyze the pros and cons of theatrical mobility, investigating situations where theatre is breaking its traditional practices of being local and urban by becoming mobile, international and rural. The main features in this context are: 1) guest performances at home; 2) guest performances abroad; 3) the importation of guest directors, performers, designers et cetera; 4) site-specific and open-air productions. The structure of the analysis is based on these features, partly derived from the historical development of theatre but partly also from the aim of contrary thinking, insisting that contrary to the widespread assumption of nomadism as something indigenous or postmodern, nomadic attitudes can also be detected in quite traditional forms of theatre making and living. The above-mentioned features are analysed in the context of Estonian theatre, drawing occasional parallels with the neighbouring country of Finland. Each section goes through three periods of Estonian theatre history: 1) the period before the Second World War when theatres belonged to societies; 2) the period between 1940 and 1991 when Estonia was a part of the Soviet Union and all theatrical activities were subject to state control; 3) the period of independence and globalization. Since each period had a different imprint on theatrical mobility, the phenomenon will be investigated in relation to the political, social and cultural contexts.

A suitable methodological tool for the research has been found already by Ott Karulin ${ }^{2}$ and Chris- topher B. Balme ${ }^{3}$ who have used Bruno Latour's actor-network-theory ${ }^{4}$ for mapping activities of a theatre and a manager respectively, taking into consideration their geographical mobility, networking, repertoire and audiences. Latour defines an actor as follows: "... any thing that does modify a state of affairs by making a difference is an actor - or, if it has no figuration yet, an actant." It means that actors embrace more than agents in Pierre Bourdieu's theory, covering not only people, groups and institutions but also objects (like, for example, texts and technology) that have agency to change the state of affairs. And network is defined by Latour as "a string of actions where each participant is treated as a fullblown mediator" ${ }^{6} \mathrm{He}$ also stresses that a network is, first of all, a methodological tool: "an expression to check how much energy, movement, and specificity our own reports are able to capture. [...] It is a tool to help describe something, not what is being described." 7 The value of the actor-network-theory lies in its intention to track relations between different actors and to describe movement instead of fixed entities. Because of that, the theory has been proved to be useful for investigating mobility in theatre and also has the potential to highlight certain aspects of artistic nomadism. Latour's discourse supports mobility and fluidity and resembles in this regard theories developed by Gilles Deleuze, Félix Guattari ${ }^{8}$, Rosi Braidotti and other postmodern thinkers. For example, he points out that the actor "is not the source of an action but the moving target of a vast array of entities swarming toward it". ' In addition, since Latour values thick description as a research 
tool, the following article describes more than it explains in the conviction that a carefully chosen and composed description also has an explanatory value.

Only certain aspects of theatrical mobility are described and analysed here, emanating from the following research questions. What factors trigger theatrical mobility? What consequences do touring and internationalisation have on artistic practices and life styles of theatre makers? And what kinds of relationships are created with audiences through theatrical mobility? Thus, the central focus of the research lies on actors (in the Latourian sense) and mobility, and not so much on networks. Nevertheless, the formation or spontaneous creation of theatrical networks, i.e. theatre troupes is tackled in the second part of the article, while relationships with spectators as important actors in networks in the first part.

\section{THE INFLUENCE OF TOURING ON THEATRE MAKERS AND PRACTICES}

The domestic mobility of theatres depends, first of all, on the national theatre system and cultural policy. In Estonia, institutional theatres are mostly bound to a certain house(s) or hall(s) where they rehearse and give performances. Contrary to this is the touring system that was widely practiced in Europe until the nineteenth century but also exists nowadays in the Netherlands, for example. The Estonian theatre never used the touring system nor had a strong central touring company as found in Sweden ${ }^{10}$ and in some other countries. In the twentieth century, semi-professional or professional theatres were established, even in small towns, so there was no great need for touring theatre. Nevertheless, almost all institutional theatres have toured to a certain extent, sometimes because of the limited size of local audiences, sometimes as a cultural mission of theatre institutions or the state's cultural policy. The first two reasons were dominant before the Second World War and all three to different extents after the war.

The first and only travelling theatre in Estonia, the Travelling Theatre (Rändteater), was established in 1926 by a group of actors, who left their home institution because of its poor artistic quality. Within two years, the Travelling Theatre joined the Drama Studio Theatre because the constant commuting tended to be exhausting and also provided an unstable income. Nevertheless, the group continued travelling all over Estonia, performing, among others, plays by Shakespeare, Schiller and Strindberg, which were all received quite warmly, even in remote places. An actor of the theatre, Alfred Mering, has described the working conditions as follows: "A two month long winter tour on a narrow-gauged railway followed. The winter was extremely cold. As always, we used a rented wagon for sleeping. On some days, we rode in horse carriages for 25-30 kilometres to be able to give a performance at some distant places from the railway in the evening." 11 The bus as a potential but exceptional vehicle of touring was mentioned only in connection with a broken bus. ${ }^{12}$ Based on the Estonian sources, guest performances seem to have been an extremely austere form of theatre making in the first half of the twentieth century.

Memoires of theatre makers concentrate mostly on exceptional events and conditions. Thus often the modes of travelling and the vehicles for transportation receive more attention than the actual performances or the reception at the various sites. It is obvious that the use of technology and technological development in general influenced not only theatre making but also the distribution and consumption of theatre, and this becomes evident also in the short history of touring practices presented in this article.

The situation described above did not change much after the Second World War. In the Soviet Union, including Estonia, all theatres had an obligation to give guest performances in the countryside and small towns. The reason for that was not so much a cultural mission or decentralization but, first of all, theatre was considered to be an important ideological and educational tool and touring was a strategy to reach a wide range of inhabitants (especially workers and farmers) providing them both professional theatre culture and didactic input. Every theatre had to have a plan that regulated the work of the theatre and that consisted of, among other things, a fixed and constantly increasing number of productions, performances (the performances 
in the country side were a separate category) and theatre visits (tickets sold). Thus, theatres were very interested in selling a high number of tickets not only because it provided them with an extra income but also because it formed a basis for state subsidies (the more tickets sold, the more spectators were 'served', thus, the higher was the subsidy).

Since the Second World War the number and percentage of guest performances has been in negative correlation with the average income per capita and the development of technology. For example, in the 1950s most Estonian theatres gave approximately half of their performances away from their permanent theatre building and city, but in the second half of the 1960s the number of guest performances started slowly to decrease because of a new trend - kolkhozes and sovkhozes also used their new buses for providing cultural entertainment for their workers, i.e. taking them to theatre performances in cities. ${ }^{13}$ The decreasing trend continued until the end of the 1970s. ${ }^{14}$ And buses as important agents in the theatre field were slowly replaced by cars that made theatre visits more individualistic and dependent on personal taste and time resources. In retrospect, one can only speculate what kind of influence guest performances had on designing the theatre-going habits and aesthetic tastes of inhabitants of rural areas. But it is obvious that the influence cannot be underestimated.

One should take into consideration that the obligation of guest performances also influenced directly the repertoire and artistic choices of theatre makers because productions had to attract country or working class people with less cultural experience and had to be adjustable for small stages with modest technical equipment. Not to mention the physical discomfort of travelling and constant adjustment to new environments from the point of view of performers. Thus, touring did not necessarily assure a stable and high standard of performances.

In the second half of the 1940s and in the beginning of the1950s, Estonian theatres used mostly covered lorries for touring, sometimes having props and actors on the same truck. Actors and technicians spent a lot of their time on the road trying to overcome the discomfort of rather primitive means of transport (cold and bumpy lorries or buses, long night drives, etc.) or the hazards on the road (broken engines and tires, snow, mud, etc.). Since there was no electricity in many performance places, an electric generator and in the case of musical productions, a piano often had to be transported. If something happened to the generator, performances were given by candle light or oil lamps. Since technology was the weakest link in the chain, theatre makers in their memoires often describe situations where they were stuck in the road or struggled with exceptional performing conditions. Sometimes, actors started guest performances by cleaning and building the stage. Sometimes, they had to wait for the spectators to arrive. (In the 1950s guest performances in the countryside started normally around 9 or $10 \mathrm{pm}$ depending on audiences and ended after midnight. ${ }^{15}$ ) Sometimes actors had to face the hostility or disinterest of the local people, or sometimes they were treated as dear guests and invited to dinners, parties or weddings. ${ }^{16}$ The system of guest performances meant that theatre companies mostly returned to their home base after the performance and the troupe did not have many possibilities to communicate with the audiences outside of the play. When theatres were on tour and stayed overnight in the performance location, completely different relationships developed between the troupe, the audience and the local people. This rather stable touring system for theatre collapsed entirely at the beginning of the 1990s when Estonia became both politically and economically independent from Russia and a major shortage of gas and other commodities affected the whole society.

Because of the reasons explained earlier (unstable artistic standards of performance and discomfort of travelling), Estonian theatre did not switch back to this half-touring regime after the economic crisis. But one should keep in mind that in addition to the theatre system and the cultural policy, the third influential factor affecting the mobility of theatres has been the lack of local audiences. This kind of problem has been facing contemporary dance groups who are also targeting international stages or, for example, the Rakvere Theatre that is situated in a town with 17,000 inhabitants and has to give more than $50 \%$ of its performances outside its home town, either in the countryside or in 
other cities with or without a theatre. Since 1985, the Rakvere Theatre has performed in 200 different cities and villages, covering 30-40 venues yearly. ${ }^{17}$ It should be mentioned that other institutions also practice touring to a limited extent. Thus, regular guest performances and a lively summer theatre tradition also explains why there are so many stationary and temporary performance locations in Estonia (see Figure 1) while professional theatre companies are located only in Tallinn, Rakvere, Kuressaare, Pärnu, Viljandi and Tartu.

Because of the rapid development of technology, touring has been made as comfortable as possible for actors and technicians. New buses and personal technological equipment also provide an almost domestic life style on the road. As Karl Kalkun (senior) argues, technology has ruined the romanticism of touring because in a warm and comfortable bus one can sleep like in your mother's lap and all the beautiful songs fade away. ${ }^{19}$

In conclusion, one can state that a kind of middle way between a repertoire and touring system has been and is practiced in Estonia as in many other European countries. ${ }^{20}$ Touring has been one of the influential factors behind the numbers of spectators for theatre. For the 1980s, the number of theatre visits exceeded the number of inhabitants in Estonia and, according to various surveys, approximately half of the Estonian population visits theatre at least once a year. ${ }^{21}$ Nevertheless, technological development has changed travelling by theatre companies and the quality of their guest performances to a considerable extent, and created at the same time, more opportunities for potential audiences to reach theatre privately, either by private cars or by television. The immobility of theatres - of course, if they are attractive enough - activates spectators, making them (in addition to performers) nomadic subjects in search of artistic experiences. In investigating touring in Estonian theatre, the importance of spectators as influential actors in theatrical networks becomes apparent. Moreover, technology as a mediator (in the Latourian sense) between performers and spectators both in their geographical and

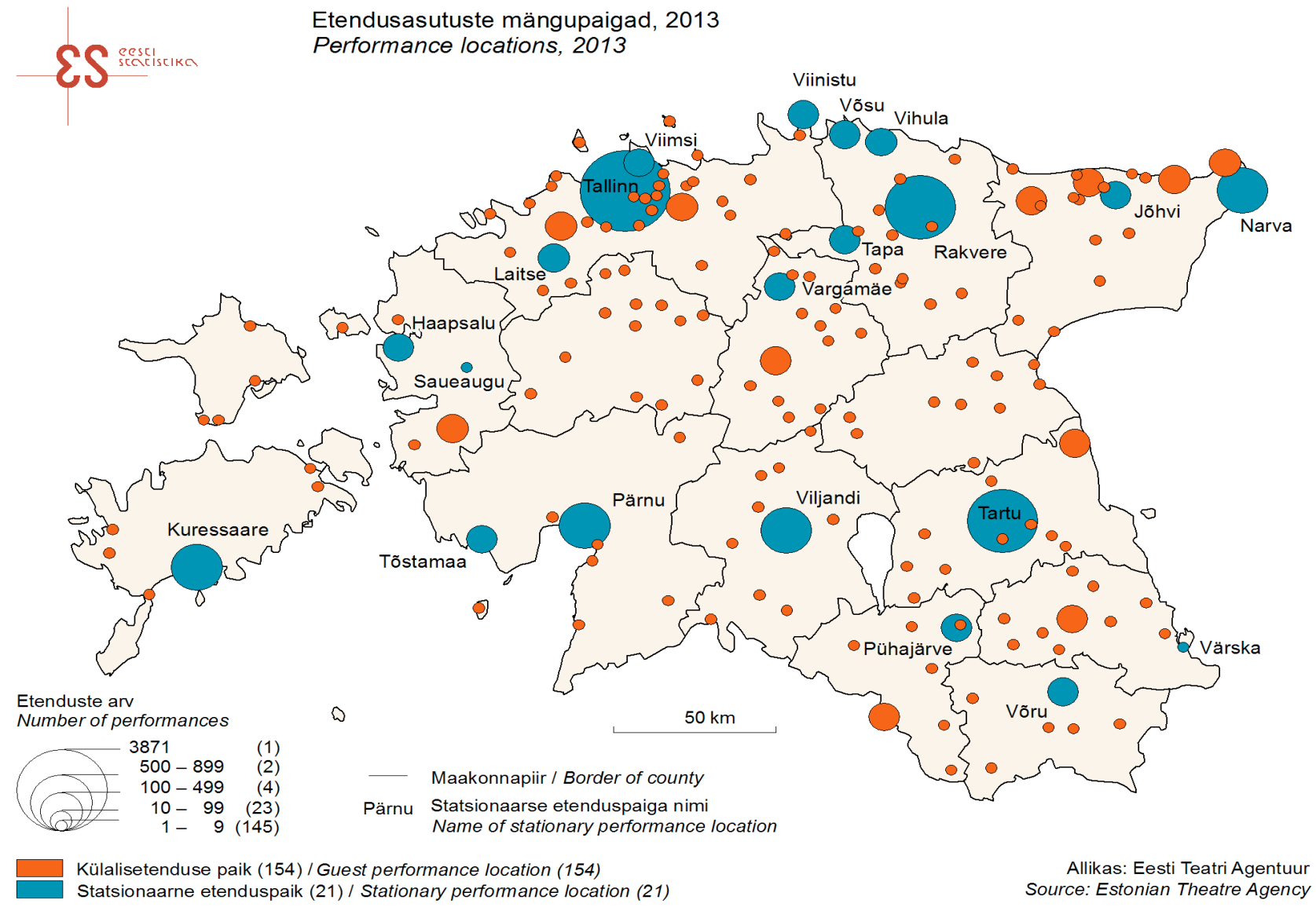

Fig. 1. Number of professional theatre performances in Estonia in 2013 by location. ${ }^{18}$ 
aesthetic means acquires the status of an actor and modifies the relationships between actors and also the artistic input.

\section{THEATRE EXPORT}

In general, the importation and export of theatre is not as widely practiced as, for example, the international film and music business or the translation of books. This can be explained by the fact that transporting performers and productions from one site to another is financially and also logistically quite complicated (not to mention the ecological footprint). This is true even in the field of dance and music theatre that has more of an international or universal character than spoken theatre. At the same time the cultural policies of the countries of the European Union stress more persistently the importance of international collaboration and exchange and the increasing impact of creative industries both in the field of economics and culture. In the following paragraphs, a historical overview of developments and trends of export of Estonian drama and theatre are given.

One notices that verbal language as the main tool of communication is the biggest obstacle in the export of theatre. Nevertheless, plays tend to be the most common international commodity, centrifugal actors in creating networks at least in the field of spoken theatre. Estonian plays by Lydia Koidula, August Kitzberg, Eduard Vilde and Hugo Raudsepp have drawn moderate attention mostly in neighbouring countries like Latvia, Russia and Finland. Estonian drama achieved its highest popularity during the period of the Soviet occupation when Estonia belonged to the union of "brother states" and thus also enjoyed the privileges of the centralized distribution system of new Soviet plays. For example, several socialist realist plays by August Jakobson were staged in 30-40 theatres all over the Soviet Union, and The Lost Son (1958) by Egon Rannet in more than 200 theatres all over the Eastern bloc, etc. ${ }^{22}$ Contemporary Estonian drama has difficulties in competing with the remarkable international success of the Soviet Estonian plays or with contemporary Finnish playwriting. The only author who has experienced a more lasting recog- nition abroad is Jaan Tätte, an actor by profession, mostly with his plays Highway Crossing, or the tale of a Golden Fish (1997, translated into 8 languages and produced more than 50 times) and The Bridge (2000, 6 languages, approx. 10 productions).

Guest performances abroad have a clear correlation with the economical welfare of the country and to a certain extent also with political freedom. Theatrical exchange with other countries expanded in Estonia in the 1930s (with the increase in economic welfare), in the $1970 \mathrm{~s}^{23}$ (with the increase in political freedom and economic capital) and in the twenty-first century (with the increase in economic welfare and the outcome of the state's and European Union's cultural policy).

Between 1956 and 1990, leading Estonian theatres performed quite often in Moscow and St. Petersburg on the occasion of different celebrations and competitions but the visits can hardly be considered as theatre export because Estonian theatre was part of the Soviet theatre system and the visits illustrated the obligatory ties between the territorial centre (Moscow) and the periphery (all the rest of the USSR). Guest performances of such peripheral theatres abroad were quite rare and especially to capitalist countries because of the Cold War. All the trips of the theatres to other states within the Soviet Union or abroad were controlled by the Ministry of Culture of the USSR and the organisation was extremely bureaucratic and time-consuming, normally taking from a year to two years and sometimes the trips were cancelled without any obvious reason. ${ }^{24}$

The first clear breakthrough towards liberation and the freedom to travel happened already at the end of the 1980s in the context of perestroika and a second one at the turn of the new century, when Estonia became a member of European Union (2004). For example in 2012, Estonian theatres gave 187 performances abroad with 50 productions in 28 countries to 66,000 spectators. (The numbers were not stable of course - in 2013 they were respectively 117 performances, 47 productions, 23 states, 25,655 spectators $^{25}$ ). The most famous Estonian director at home and abroad is currently Tiit Ojasoo, who often works in tight collaboration with scenographer, director and performance artist Ene-Liis 
Semper. One fifth (36) of all the guest performances abroad were presented by Ojasoo's theatre NO99. In second place was the project-based theatre the R.A.A.A.M. (31), in third place was the production house of contemporary dance the Kanuti Gildi SAAL (20) and fourth was the Estonian Puppet and Youth Theatre (18).

Unusually, it is the productions by the Theatre NO99 and R.A.A.A.M which are mostly wordbased that are the most heavily exported at the moment, while dance and children's theatre (often small scale productions) traditionally represent the more mobile forms of theatre. ${ }^{26}$ The largest number of performances were given in Germany but the most often visited countries were neighbors Russia and Finland. ${ }^{27}$ (Similarly the most visited countries by Finnish companies were respectively Sweden, Russia and Germany during this period..$^{28}$ )

For the sake of balance, the importation of theatre should also be included in this overview. Since approximately $25 \%$ of the Estonian population is Russian speaking, many theatres from Russia make regular visits to the country: for example in 2013, 17 out of 65 productions were performed by theatres from Russia. ${ }^{29}$ Otherwise it is difficult to make any convincing generalizations about the cultural background of companies and performers coming from Europe because often the groups are multi-national, sometimes including Estonian performers. As concerns genres, contemporary dance is an important feature from the Western countries, while drama is the main import from the Eastern countries.

In conclusion, one can state that the biggest obstacles to international theatre export are the limited financial resources, as well as the language and mental barriers. (From a historical or world perspective, political restrictions should also be mentioned.) But the first step to overcoming these obstacles concerns theatre makers and managers who have to depart from their comfort zone and start looking for collaboration and exchange outside of their own theatre houses. A similar kind of message was given by the Minister of Culture of Finland, Paavo Arhinmäki, when he nominated the state prize of performing arts in 2013 to three small theatres (two from Finland and one from Estonia) for their artistic collaboration and exchange of actors. ${ }^{30}$ Despite this, guest performances abroad create looser and more occasional relationships with spectators compared to touring in the homeland but they definitely strengthen cultural ties between theatre institutions and countries. This leads us to the next topic.

\section{THE IMPORTATION AND EXPORT OF GUEST DIRECTORS, PERFORMERS, DESIGNERS, ETC.}

Directors and designers travelling across the borders of their home country are the most common and the easiest form of theatrical mobility nowadays, if artists have achieved a certain fame at home or abroad, of course. In their work, language issues can be solved quite easily. But historically the situation has been different. Already in the first half of the twentieth century, several Estonian actors (Paul Pinna, Theodor Altermann, Liina Reiman, etc.) were working temporarily either in Germany, Russia or Finland, performing in local languages, not to mention quite regular study trips of all kinds of theatre makers to Europe or Russia. The situation changed considerably after the Second World War. First, there were obligatory instructional ties with Moscow and Leningrad, but Estonian-speaking actors hardly performed in Russia because of their heavy accent in Russian (in Soviet movies actors from the Baltic countries played mostly Germans because then their accents were not distracting ${ }^{31}$ ). For example Voldemar Panso, the leading director of the time and the head of the Estonian Theatre School, travelled quite a lot as a tourist outside of the USSR but hardly with his troupe or productions and never produced anything abroad. Panso, like several other established directors and actors who enjoyed the privileges of travelling, wrote detailed reports about the foreign countries they visited, ${ }^{32}$ paying special attention to everything that differed from Soviet conditions. For example in 1965, the Estonian Drama Theatre had guest performances in Helsinki and as an outcome of this an essay "About Finland, Finns and Finnish Theatre" was written by Panso, giving a detailed overview about Finnish nature, architecture, people and theatre. ${ }^{33}$ Finland was also the first capitalist country with which the exchange of stage directors was carefully established in $1960 .{ }^{34}$ Nevertheless, since the background of 
guest directors and ideological stances of their productions were rigorously controlled during the Cold War, not much of significance was born out of this kind of cultural exchange across the borders of the Soviet Union. The situation did not change rapidly after the (re)independence of Estonia because international collaboration continued to have certain obstacles.

Analyzing the dynamic of theatrical mobility by theatre makers, one can repeat again the biggest obstacles of international exchange - the lack of money, linguistic difficulties and mental barriers. In addition to that, one can detect two contrary tendencies at work: first the search for novelty and new perspectives, such as exoticism, and at the same time conservatism in accepting novelty and new perspectives. To put it plainly, guest directors or designers often experienced the feeling of an intellectual and emotional vacuum when working abroad and the spectators at the same time could experience a sense of estrangement from the production; this might happen even when the production dealt with universal topics. ${ }^{35}$ Despite certain reservations, however, guests definitely broke the routine of theatre making and sometimes led to wonderful works. Directors who have been able to find a common language with local actors and audiences have become persistent guests in Estonia. For example, Adolf Shapiro (since 1971) and Sasha Pepelyaev (since 2002) from Russia and Georg Malvius (since 1989) from Sweden have influenced the Estonian theatre field quite a lot with their successful productions and working methods. Often, guest directors, who work in tight collaboration with certain set and costume designers or assistants, take their colleagues with them abroad, making the exchange multidimensional.

The importation of guest directors or performers not only brings cultural diversity but also intensifies professional competition and raises artistic standards. This has led to the situation where the Estonian opera companies Estonia and Vanemuine have become more international: most opera and ballet directors are invited from abroad, and the leading roles are performed by guest singers and the majority of dancers of the ballet troupes are from other countries using the theatres often as a spring board to Western Europe or America. Local opera or ballet artists work either at home or abroad, while less talented ones are forced to find other possibilities to make a living. Another issue that has been problematic is the different salary standards for local and guest artists. Since the average income in Estonia has been among the lowest in the European Union, guest artists' fees often exceed the ones paid for locals because living standards in the country of origin has been taken into consideration. Thus, the negative aspects of theatrical internationalization include an inequality in salaries, a negative (displacing) impact on local theatre cultures and cultural homogenization.

Erika Fischer-Lichte has pointed out that one of the most urgent issues facing theatre research today is the question of how theatre is affected by the rapid processes of globalization. Three rather new phenomena play important roles in the process: internationally composed opera, dance and theatre companies; the ubiquitous workshop culture; and international theatre festivals. Addressing them does not simply mean carrying out intercultural studies on theatre, but - in many respects - opening up a completely new field. ${ }^{36}$ Artists and troupes travelling freely from one country to another have the biggest potential to represent truly nomadic subjects.

In conclusion it can be stated that internationalization and growing trends of cultural exchange definitely need more investigation and conceptualization that exceeds the limits of the current article. Opposing the problems of globalisation, more attention should also be paid to local, regional mobility.

\section{SITE-SPECIFIC AND OPEN AIR PRODUCTIONS}

In this section, the summer theatre tradition in Estonia will be analysed since it offers interesting examples of theatrical mobility. The term 'summer theatre' (suveteater in Estonian) covers all productions staged during the summer months, mostly from June to August, the off-season for professional theatre, both indoors and outdoors, either in found places or in permanent theatre houses (however, the latter happens rather rarely), either by professionals or by amateurs (the latter is rare by contrast with 
other Nordic countries). Institutions that tend to perform only in the summer are also sometimes named and called summer theatres, for example Emajóe Suveteater in Tartu. It is also noteworthy that summer theatre activities are not regulated by state or municipalities and usually also not by big theatre institutions. Therefore, they can mostly be considered as the personal initiative of theatre makers or managers, often driven by two contrary wishes to earn some extra income and to spend the summer vacation in a pleasant environment (preferably outside of the city) and in good company.

There are several reasons why summer theatre has not deserved much attention in theatre histories or statistics. First, summer theatre tends to be semi-professional, semi-amateur and because of the latter it has often fallen out of the study of professional theatres. In theatre histories, summer productions are sometimes briefly tackled in chapters that analyse city theatres and the cultural life in the area. Second, often summer theatres provide light entertainment that has not been valued highly in theatrical research. And third, the deficit of information covering most areas of a country and most artistic projects can be considered as a main obstacle for extensive research.

Both local theatres and guest troupes started to give open-air performances more regularly in the second half of the nineteenth century, but these spectacles were mostly just removed from indoors to outdoors and performed on a raised stage. Special open-air productions on an unmarked stage area appeared in Estonian at the beginning of the 1920s. Throughout the twentieth century, theatres performed sporadically during the summer and sporadically also outdoors. But a sudden change occurred in 1995 as a result of the highly successful summer production of The Three Musketeers in the Tallinn City Theatre (Fig. 2) that earned as big a profit as all the other productions of that theatre during the year. This event encouraged not only institutional and private theatres but also independent directors and theatre managers to produce special summer productions, mostly with newly composed professional troupes in diverse found places and spaces (some indoors, some outdoors, some in the cities, but mostly in the countryside). During the last

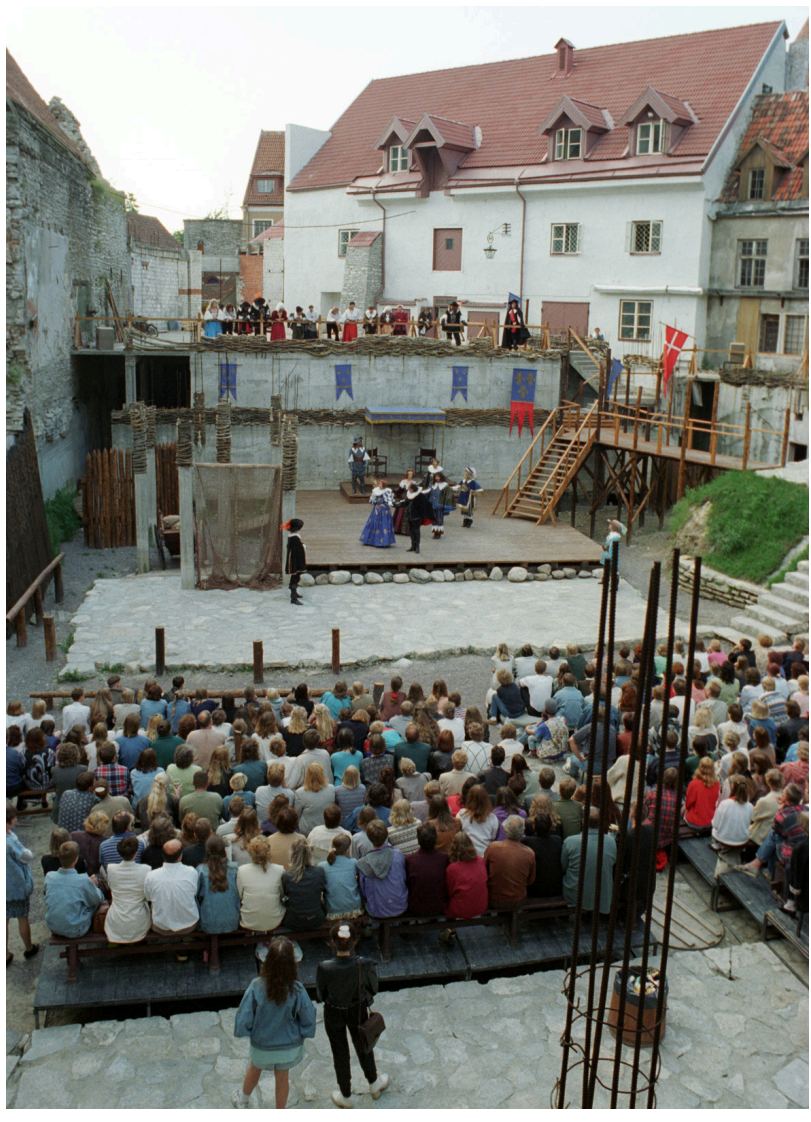

Fig. 2. The Three Musketeers (1995), Tallinn City Theatre, directed by Elmo Nüganen. A former construction site is transformed into an open-air theatre. Photo: Priit Grepp.

10-15 years there have been approximately 30-40 new summer productions every year and altogether 40-60 productions per season.

In general, Estonian summer theatre implies traveling and settling on new territories both by theatre makers and spectators. Summer productions can take place inside or outside of manor houses, beside picturesque river bends, in ancient castle ruins, on small islands, in the forest or a bog, etc. (Fig. 3) By contrast with the Finnish situation, ${ }^{37}$ Estonian theatre makers are rarely faithful to one specific location for summer performances but rather tend to be in constant search for new exciting environments. Furthermore, the comfort of audiences is not an important issue in Estonian summer theatre, but rather the aim is to provide new or unusual experiences.

Summer theatre should not be analyzed as an 
isolated phenomenon. The so-called Estonian summer culture in general underwent a boom at the end of the last century. In addition to various theatre productions, folk and popular music festivals, and concerts of classical music in small towns (e.g. the Tamula Lake Music concerts in Vôru) or in rural areas (e.g. the Leigo Lake Music) should also be taken into account. These open-air events targeted the general public, combining art, the natural environment, and food and drink. Summer culture is often consumed by people who would not attend an indoor performance of classical music and would probably not go to the theatre either. Such extraordinary and 'exclusive' events became a compulsory component of the vacations of the nascent middle class and a natural part of their lifestyle, thereby acquiring a considerable symbolic importance. Openair events often take people to new, naturally beautiful parts of Estonia, providing an opportunity for pleasantly spending time with family or friends, and maybe even, with a little luck, enjoying an artistic experience.

In the Nordic countries, where the summers are short and often cold and rainy, one has to catch every sunny day and ray of sunshine. One must also emphasize the implicit connection with nature felt by Estonians, who are for the most part first or second generation city-dwellers. This is manifested in the many pantheistic features of their worldview and, more specifically, in the summer cottages in the countryside that are owned by almost every family. It means that during the summer season most of the inhabitants practice a small scale nomadism commuting back and forth between their city and country home or moving permanently to the countryside and accepting, through that, a new identity and lifestyle for that period.

The importance of national epics and their popularity among summer audiences in Estonia may be a sign of a nostalgic yearning for national ideals and a feeling of solidarity. The large number of spectators at open-air performances intensifies the feeling of solidarity that was so strongly felt in the recent past, yet has all but been forgotten in everyday life and confirms the existence of certain traditional or common ideals.

Despite accelerated urbanization and inter-

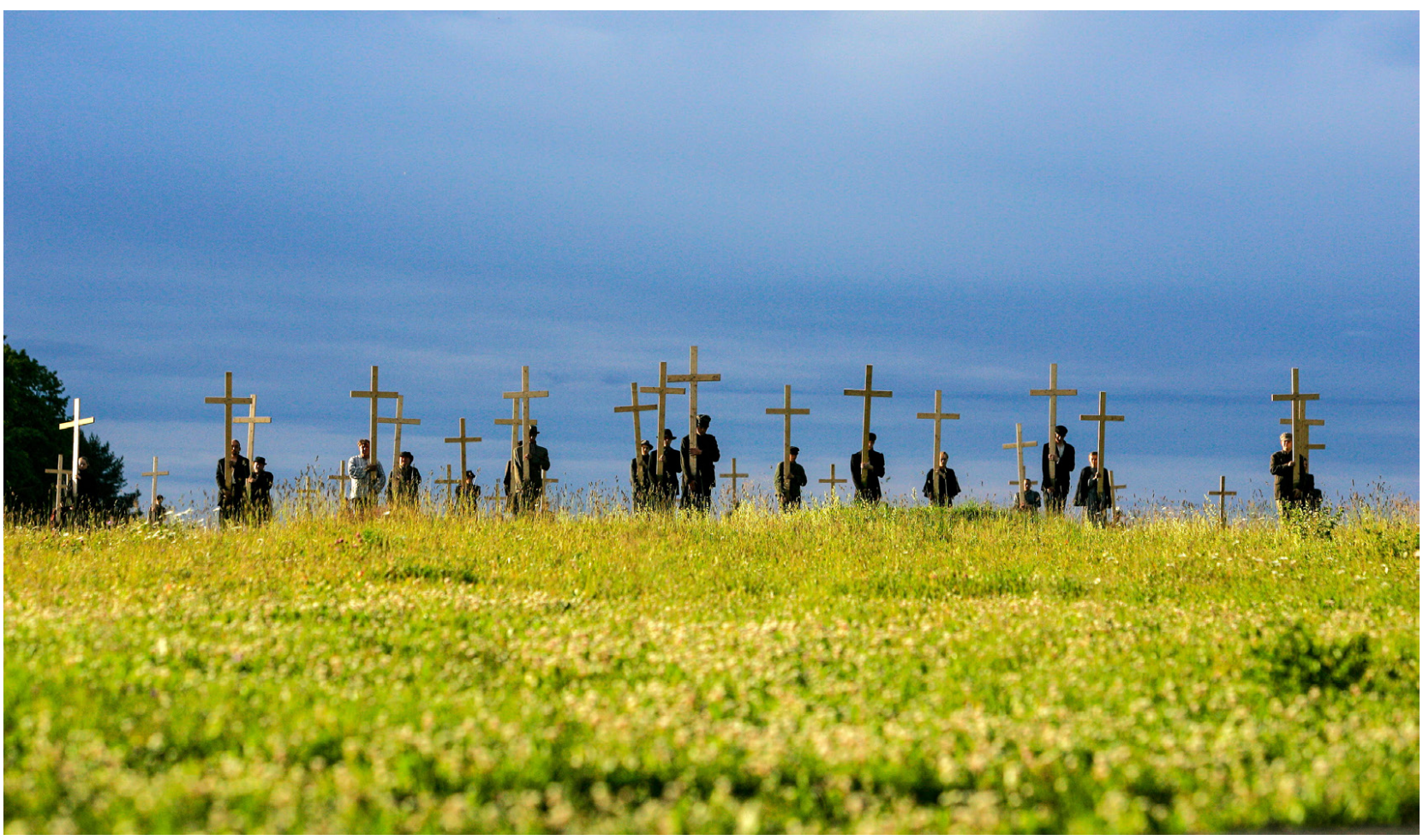

Fig. 3. The Republic of Wargamäe (2008), Tallinn City Theatre, directed by Elmo Nüganen. Photo: Siim Vahur. 
nationalization, theatre makers and audiences in Estonia still have strong bonds not only with nature and the countryside but also with local identities and communities. Theatre practice is a way of bridging urban and rural cultures and life styles. The consumption of culture in a natural environment is an attempt by a recently urbanized people to blend nature and culture. The symbiosis of nature and art, the low and the high, the everyday and the elitist appears to the Nordic people living in twenty-first-century post-modern society to be the most natural possible combination. In addition, summer culture as a special form of art and living has a similar effect both on artists and spectators, offering them the role of nomadic subjects for a certain and short period of the year. Artists are more or less bound to one or two locations, but spectators of summer culture are welcome almost anywhere where cultural events are performed.

\section{CONCLUSIONS}

This article provides an overview of different types of mobility or nomadism in the field of theatre using Estonian theatre history as empirical material. Bruno Latour's actor-network-theory served as a background for the research and brought to the fore the following questions. What factors trigger theatrical mobility? What consequences do touring and internationalisation have on artistic practices? And what kinds of relationships are created with audiences through theatrical mobility?

Based on the analysis presented above, it is possible to state that touring and guest performances at home tend to depend mostly on the theatre system and cultural policy but, to a large extent, they are also dependent on the number of local spectators, the economic conditions and technology. The latter can be related mostly to the development of vehicles for transportation (trains, horse carriages and lorries were replaced by comfortable buses and later on personal cars) and to the development of theatre technology (and aesthetics) that set higher standards for performance places. In Estonia, the number and percentage of guest performances has been in negative correlation with the average income per capita and technological progress.

Guest performances abroad have had a clear correlation with the economic welfare of the country and to a certain extent also with political freedom. But even when economic, political and cultural conditions are favourable to an international exchange of productions or theatre makers, language and mental barriers cannot be eliminated or overlooked so easily. The positive impact of internationalization in the performing arts lies in an increase of cultural diversity, artistic standards and professional competition. Nevertheless, the negative aspects of international mobility - the displacement of local theatre cultures and cultural homogenization - should also be kept in mind. An alternative strategy for cultural diversity can be found in the acceleration of domestic theatrical mobility in the framework of summer theatre. While nomadism is mostly related to the lifestyle and identity of artists, summer theatre and culture create an opportunity for spectators to experience nomadism in more local spaces such as in a city or rural venue. Thus, the aims or forces behind theatrical mobility and networking, and also the subjects, institutions and objects (like for example, the environment, technology and texts) as actors in these networks deserve further research and international comparison. 


\section{NOTES AND REFERENCES}

1 The research for this chapter has been supported by the Estonian Research Council (grant "Emergent Stories: Storytelling and Joint Sensemaking in Narrative Environments"; PUT 192).

2 Ott Karulin, Rakvere Teater "täismängude” otsinguil aastail 1985-2009, PhD thesis, Tartu Ülikool, Tartu 2013.

3 Christopher B. Balme, "The Bandmann Circuit: Theatrical Networks in the First Age of Globalization" in Theatre Research International, vol. 40, no. 1, 2015, pp. 19-36.

4 Bruno Latour, Reassembling the Social. An Introduction to Actor-Network-Theory, Oxford University Press, Oxford 2005.

5 Ibid, p. 71.

6 Ibid, p. 128.

7 Ibid, p. 131.

8 Also the terms 'network' and 'rhizome' have essential similarities.

9 Ibid, p. 46.

10 S. E. Wilmer, Pirkko Koski, The Dynamic World of Finnish Theatre. An Introduction to its History, Structures and Aesthetics, Like, Helsinki 2006, p. 128.

11 Alfred Mering, Elu lugu. Teatrimälestused, Eesti Raamat, Tallinn 1986, p. 52.

12 Ibid., p. 43.

13 Jaak Rähesoo, Eesti teater. Ülevaateteos. I, Eesti Teatriliit, Tallinn 2011, p. 298.

14 Jaak Viller, Teatriorganosatsiooni areng Eestis XX sajandi II poolel, MA thesis, Tartu Ülikool, Tartu 2004, pp. 21, 52.

15 Karl Kalkun senior, Karl Kalkun junior, Teatrimemuaare, Vanemuise Seltsi Kirjastus, Tartu 2000, pp. 148-9.

16 Ibid, pp. 131-5, 146-50; Reet Neimar, Pille-Riin Purje, Jüri Järvet, Narr ja Kuningas, Eesti Teatriliit, Tallinn 2009, p. 100.

17 Karulin, op. cit., pp. 66-70.

18 Eesti teatri Agentuur, http://statistika.teater.ee/stat/main (accessed 15 September 2014).

19 Ibid, p. 134.

20 Hans van Maanen, Joshua Edelman, Magdolna Balkanyi, Mathias P. Bremgartner, Louise Hansen, Anneli Saro, Beate Schappach, Hedi-Liis Toome, Attila Szábo, Maja Šorli, "Theatre Systems Compared" in Amfiteater, vol. 3, no. 1 (forthcoming).

21 The number of steady theatre goers in 1985 was $88 \%$ of respondents, in 1993 63\%, in 1998 44\%, in 2003 and 2006 53\% (Malle Järve, "Kultuuritarbimise trendid 1990ndate Eestis" in Rahvakultuur ingliska ja internetiga,
Rahvakultuuri Arendus- ja Koolituskeskus, TPÜ RASI, TPÜ Nüüdiskultuuri Uurimiskeskus, Tallinn 1999, p. 32; Kultuuritarbimise uuringu aruanne 2006, www.andmemasin.eu, p. 7.)

22 Rähesoo, op. cit., pp. 287-8, 343.

23 Eesti sónateater 1965-1985, I köide, EMTA lavakunstikool, Eesti Teatriliit, ETA Underi ja Tuglase Kirjanduskeskus, Tallinn 2015, p. 37.

24 Ibid., pp. 38-9.

25 Eesti teatristatistika 2013, http://statistika.teater.ee/stat/ main/show/29 (accessed 15 September 2014).

26 In 2011, at the top of the list of Finnish theatre exports was dance theatre and circus: 42 Finnish dance groups and dancers performed in 28 different countries to 59,000 spectators and 14 circus troupes performed in 25 countries to 110,000 spectators. Considering the clear dominance of spoken theatre in Finland, only 30 theatres and groups (among them five puppet theatres for children) were performing abroad for 31,000 spectators. (Suna Vuori, "Teatteri ei ole vientibisnes" in Helsingin Sanomat, 13 May 2013, p. C1.)

27 Lühiülevaade 2012. aasta Eesti teatristatistikast, http:// statistika.teater.ee/stat/main/show/27 (accessed 1 April 2014).

28 Vuori, op. cit.

29 Eesti teatristatistika 2013, op. cit.

30 "Ministeri Arhinmäki jakoi musiikin, näyttämötaiteen ja tanssitaiteen valtionpalkinnot", http://www.minedu. fi/OPM/Tiedotteet/2013/11/musiikki_nayttamo_tanssi_valtionpalkinnot_2013.html?lang=fi (accessed 1 April 2014).

31 See for example the documentary "Nazies and blondes" (2008, director Arbo Tammiksaar, Kuukulgur Film, Subjektiv Filma).

32 Voldemar Panso, Laevaga Leningradist Odessasse, Eesti Riiklik Kirjastus, Tallinn 1957; Voldemar Panso, Maailm Arlekiini kuues, Eesti Raamat, Tallinn, 1973; Ants Eskola, Näitleja on ajastu lühikroonika. Mälestused, Eesti Raamat, Tallinn 1986.

33 Voldemar Panso, "Soomemaast, soomlastest ja soome teatrist" in Maailm arlekiini kuues, op. cit., pp. 36-48.

34 Karin Kask, Eesti nóukogude teater 1940-1965. Sónalavastus, Eesti Raamat, Tallinn 1987, p. 313.

35 Sven Karja, Anneli Saro, “Teatrielu 2003: saateks ja tagasivaateks" in Teatrielu 2003, Eesti Teatriliit, Tallinn 2004, pp. 12-14.

36 Erika Fischer-Lichte, "Interweaving Cultures in Perfor- 
mance: Theatre in a Globalizing World" in Theatre Research International, vol. 35, no. 3, 2010, pp. 293-4.

37 Pälvi Laine, Teatteri ilman esirippua - tila suomalaisessa kesäteatterissa, MA thesis, Helsingin yliopisto, Helsinki 1998. 
